ROCZNIKI HUMANISTYCZNE

Tom LXVII, zeszyt 11 - 2019

DOI: https://dx.doi.org/10.18290/rh.2019.67.11-4

WIKTOR PSKIT

\title{
THE POST-VATICAN II ROMAN MISSAL IN ENGLISH: A PRELIMINARY COMPARISON OF TWO ENGLISH TRANSLATIONS*
}

\begin{abstract}
A bstract. Following the Second Vatican Council the Roman Catholic liturgy has undergone significant changes. One of them is the shift towards the vernacular as the language of liturgy. First of all, the post-conciliar liturgical reform resulted in a considerable reduction in liturgical texts. Secondly, the shift towards the vernacular entailed further changes, including substantial departure of some translations (e.g. English or German) from the original Latin text of the socalled editio typica of Paul VI's Missal. This paper is concerned with the differences between the two English translations of the postconciliar Roman Missal (1969/1970), i.e. the 1973 version and the currently used 2010 translation. The analysis has a preliminary character as it deals with selected parts of the Roman Missal in English. The paper focuses on the major differences at the levels of lexis and grammatical structure and it seeks to demonstrate how two radically opposing approaches to the translation of the language of worship contribute to the emergence of texts that significantly differ in their content, style and emphasis.
\end{abstract}

Key words: Roman Missal; liturgical language; hieratic language; English translation.

\section{INTRODUCTION}

This paper offers a cursory glance at two English translations of the postVatican II Roman Missal. Its major goal is to discuss the key differences between the two translations in the light of a more general issue of liturgical

WIKTOR PSKIT, PhD - University of Łódź, Institute of English Studies, Department of English and General Linguistics; address for correspondence — E-mail: wiktor.pskit@uni.lodz.pl

* Parts of the research discussed below were presented at the following conferences: Jezzk religijny dawniej i dziś (w kontekście teologicznym i kulturowym) (Poznań 2016, 2018), 13th IASSAIS World Congress of Semiotics (Kaunas 2017), Personal Identity through a Language Lens (Łódź, 2017). I would like to thank the participants of the conferences for their helpful comments. All shortcomings are mine. Some of the ideas and data presented below are discussed in Polish and juxtaposed with the Polish version of the Roman Missal in Pskit $(2017,2018)$. 
language employed for the purpose of worship in Roman Catholicism. The differences stem from divergent approaches to the translation of liturgical texts, which, however, are based on two distinct concepts of the language of liturgy (hieratic/sacred language vs. non-hieratic language). While there is a diversity of rites within broadly understood Catholic Church (including a variety of Eastern liturgical traditions), this paper is specifically concerned with the most widespread one, i.e. the Roman rite, and furthermore, its focus is narrowed down to the liturgy of the Mass, leaving aside other aspects of liturgy such as the administering of sacraments or the Divine Office (also referred to as the Breviary).

\section{THE LANGUAGE OF ROMAN CATHOLIC LITURGY}

The language of worship within Roman Catholicism has evolved over time. For most of the history of the Roman rite, with minor exceptions (cf. Fortescue, Jungmann, Reid, Lang), its language was a kind of universal language, initially Greek and then Latin, since it was viewed as a 'vehicle of unity' and stability of faith (cf. Dobszay, Lang). While what could be dubbed Christian Latin was by no means a homogeneous phenomenon (cf. Burton, Coleman, Lang), one register within this broader variety of Latin can be distinguished on the basis of its lexical, morphological and syntactic properties, viz. liturgical Latin (Mohrmann). Based on her studies on early Christian Greek and Latin, Mohrmann argues that the language of Roman Catholic worship was consistently a hieratic (sacred) language with the following characteristics: reliance on older linguistic forms and structures (archaisms), introduction of foreign elements (mainly at the level of vocabulary, e.g. Hebrew and Greek elements in liturgical Latin), and use of rhetorical figures typical of oral style (e.g. parallelism and antithesis, rhythmic clausulae, rhyme and alliteration). The latter feature is significant here since the language of the Roman rite to a large degree inherits the key characteristics of the ancient Roman oratorical style. Importantly, thus understood hieratic language is distinct from the language of everyday communication. The sacred language is a product of deliberate stylization, and hence a kind of quasi-artificial language. In Mohrmann's view, Latin replaced Greek as the language of Christian worship only when an appropriately stylized hieratic variety of the language developed. Mohrmann's publications approximately coincide with the time of liturgical reform in 
Roman Catholicism, culminating in the shift from Latin to vernaculars. It is particularly interesting to note that according to Mohrmann, at that time vernacular languages did not yet have hieratic varieties that would be suitable for liturgy.

Similar ideas on liturgical language are expressed by Crystal in the context of English. In his view, liturgical English should include archaic grammatical forms (e.g. older pronominal forms such as thou, thee, thy, thine, ye instead of you; the older variant of the second-person form of be in present tense: art instead of are; the archaic plural brethren), lexical archaisms (e.g. vouchsafe, thrice, behold, etc.), and certain syntactic structures (e.g. unusual word order, frequent use of vocative, imperative including the subject). The basic characteristics of hieratic (sacred) language in the sense of Mohrmann and Crystal provide an important linguistic background for our discussion of two English versions of the reformed Roman Missal introduced by Pope Paul VI.

\section{THE PAULINE ROMAN MISSAL IN ENGLISH: A HISTORICAL BACKGROUND}

The following events led to the emergence of the English translations officially approved for use in liturgical celebrations within the Roman rite. The Vatican II constitution on the liturgy (Sacrosanctum Concilium, 1963) postulates that vernacular languages be introduced into the liturgy of the Mass, but, as observed by many (cf. Gamber, Ratzinger, Lang), it only permits a limited amount of the vernacular with most of the text still being in Latin. For example, until 1967 it was maintained that the central prayer of the Mass, the Roman Canon, should remain in Latin. This reservation was soon overlooked and in 1970s Latin was almost thoroughly erased from Roman Catholic liturgy ${ }^{1}$ and replaced by vernaculars. The new Roman Missal promulgated by Paul VI (1969) is written in Latin and constitutes the so-called typical edition (editio typica), intended as a source text for translation into vernaculars. Since the publication of the Pauline missal, the issue of liturgical translation has been an object of an ongoing debate within the Catholic Church (cf. Dobszay, Elliott, Kalekas, Lang, Marini, Pecklers, Schuler).

\footnotetext{
${ }^{1}$ The exceptions include the liturgy celebrated according to the Roman Missal (1962) representing the so-called Tridentine Mass - and papal liturgy.
} 
The question of how to translate the Latin original into vernaculars has been addressed by the ecclesial authorities a number of times. In his speech at a meeting with translators, Paul VI (10 November 1965) suggests that "the language used in the liturgy should always be worthy of the noble realities it signifies ... set apart from the everyday speech of the street and the marketplace ", emphasizing the need for "clarity of language and dignity of expression ... in the vernacular translations of liturgical texts". This clearly corresponds to the general concept of sacred (hieratic) language outlined above in section 2. However, the first set of guidelines for translation of liturgical texts prepared by the commission authorized by Paul VI to work on the reformed Missal is the instruction Comme le prévoit (25 January $1969)^{2}$. Although the instruction mentions a dignified style and traditional religious language, in many respects it postulates what amounts to be a "revolutionary" approach to the translation of liturgical books. First of all, it argues that rendering the content can occur without preserving the formal structure of the original, which seems to echo the tenets of Nida's dynamic equivalence, one of the popular trends in translation theory of that time. What constitutes the most revolutionary element is permitting some degree of adaptation, thus making the texts intended for public worship dependent on the translator's subjective judgments.

The instruction also presupposes that there should be a single vernacular text for a language spoken in several countries. Such translations are to be produced by international commissions appointed by the relevant episcopal conferences. In the case of English, the relevant body is dubbed International Committee for English in the Liturgy (henceforth ICEL), established as early as 1964. Soon it turned out that, while preparing the first English translation of the reformed Roman Missal, members of ICEL adhered to the principles of Comme le prévoit, mostly based on dynamic equivalence. As will be shown below in section 4, while dynamic equivalence is an approach that might be quite useful with reference to a number of literary genres (including some religious genres), its merits in the context of liturgical English are questionable. Anyway, the methodology based on Comme le prévoit guided the preparation of the first translation of the Pauline Roman Missal into English, officially approved in 1973 (in liturgical use since 1974). The 1973 English translation (henceforth ICEL 1973) is characterized by a significant departure from the hieratic nature of the

\footnotetext{
${ }^{2}$ http://www.ewtn.com/library/curia/conslepr.htm, DOA 22.05.2018.
} 
language of Christian worship. It lacks archaic lexical and morphological forms, and syntactic structures. It deliberately avoids use of more complex or sophisticated syntactic constructions. It also exhibits a tendency to employ colloquial, sometimes even banal, language. There are also frequent omissions with respect to the Latin original.

These features of ICEL 1973 soon became an object of criticism on theological and linguistic grounds (cf. Elliott, Kalekas, Schuler). Consider a more recent summary of the situation (in theological perspective) by the late cardinal Francis George, an American prelate involved in supervising the work on the current version of the missal in English ${ }^{3}$ :

First of all, the first full translation of the missal of Paul VI was ideologically charged. Since the liturgy, along with Sacred Scripture, is the primary carrier of the tradition that unites us to Christ, the loss of the theology of grace, the domestication of God, the paraphrasing that deliberately omitted nuances of understanding, the deliberate omission of biblical references in the liturgical text itself, etc. left the church for forty years without a way of worship that adequately expressed our faith.

With the publication of the second typical edition of the Roman Missal (1975), ICEL began work on the revised translation into English. The new translation was ready by 1998, but it did not get the approval of the Holy See, partly because the third typical edition of the missal was underway (it appeared in 2002) and, more importantly, because the Vatican prepared a new instruction with guidelines for translation into vernaculars. Generally speaking, the instruction Liturgiam authenticam (2001, below LA) rejects the approach presented in the earlier Comme le prévoit document in favour of the notion of sacred (hieratic) language. Above all, it seems to follow at least some of the principles of formal equivalence as opposed to dynamic equivalence (cf. Nida). From the theological point of view, it requires that vernacular versions be:

... marked by sound doctrine, which are exact in wording, free from all ideological influence, and otherwise endowed with those qualities by which the sacred mysteries of salvation and the indefectible faith of the Church are efficaciously transmitted by means of human language to prayer, and worthy worship is offered to God the Most High. (LA, no. 3)

\footnotetext{
${ }^{3}$ https://www.americamagazine.org/content/all-things/role-archbishop-interview-cardinal-francisgeorge DOA 18.04.2019
} 
The text of Liturgiam authenticam ( $L A)$ contains some diagnosis of the situation of vernacular texts at the turn of the millennia, recognizing cases of 'linguistic abuse':

... translations of liturgical texts in various localities stand in need of improvement through correction or through a new draft ... The omissions or errors which affect certain existing vernacular translations - especially in the case of certain languages - have impeded the progress of the inculturation that actually should have taken place. Consequently, the Church has been prevented from laying the foundation for a fuller, healthier and more authentic renewal. ( $L A$ no. 6$)$

The above definitely refers, among others, to English, and it is not surprising that one of the first vernacular versions of the third edition of Missale Romanum was the English one.

In the following passage, Liturgiam authenticam stresses the need to be faithful to the Latin original, to obey the general principle of the 'organic growth' of liturgy (cf. also Reid 2005), to avoid omissions or additions, and to constrain adaptation:

The Latin liturgical texts of the Roman Rite, while drawing on centuries of ecclesial experience in transmitting the faith of the Church received from the Fathers, are themselves the fruit of the liturgical renewal, just recently brought forth. In order that such a rich patrimony may be preserved and passed on through the centuries, it is to be kept in mind from the beginning that the translation of the liturgical texts of the Roman Liturgy is not so much a work of creative innovation as it is of rendering the original texts faithfully and accurately into the vernacular language. While it is permissible to arrange the wording, the syntax and the style in such a way as to prepare a flowing vernacular text suitable to the rhythm of popular prayer, the original text, insofar as possible, must be translated integrally and in the most exact manner, without omissions or additions in terms of their content, and without paraphrases or glosses. Any adaptation to the characteristics or the nature of the various vernacular languages is to be sober and discreet. ( $L A$ no. 20)

Furthermore, while comprehensible, vernacular texts should exhibit a dignified style, reflecting the beauty of the prayers of the Roman rite:

So that the content of the original texts may be evident and comprehensible even to the faithful who lack any special intellectual formation, the translations should be characterized by a kind of language which is easily understandable, yet which at the same time preserves these texts' dignity, beauty, and doctrinal precision. By means of words of praise and adoration that foster reverence and gratitude in the face of God's majesty, his power, his mercy and his transcendent nature, the trans- 
lations will respond to the hunger and thirst for the living God that is experienced by the people of our own time, while contributing also to the dignity and beauty of the liturgical celebration itself. ( $L A$ no. 25)

Finally, and most notably in the light of the discussion in section 2 above, Liturgiam authenticam anticipates that adherence to its principles will lead to the emergence of hieratic varieties of vernacular languages:

... the observance of the principles set forth in this Instruction will contribute to the gradual development, in each vernacular, of a sacred style that will come to be recognized as proper to liturgical language. ( $L A$ no. 27 )

The revised translation of the third edition of the Roman Missal into English was approved in 2010, and started to be used in worship since the Advent of 2011. A brief analysis below attempts to demonstrate how the two largely contradictory instructions produced by the ecclesial authority contributed to the emergence of two significantly different English translations of the main liturgical book of the Roman rite.

\section{DIFFERENCES BETWEEN ICEL 1973 AND ICEL 2010}

The two sections below provide a sample of texts demonstrating the relevant differences between the two English translations of the Roman Missal. The following abbreviations are employed: MR for the original Latin of the typical edition (Missale Romanum), ICEL 1973 for the first official English translation approved in 1973, and ICEL 2010 for the revised English version.

\subsection{THE ORDINARY OF THE MASS: ICEL 1973 VS. ICEL 2010}

The so-called Ordo Missae, or Ordinary of the Mass, includes the texts of prayers that remain the same throughout the liturgical year. These are the prayers that the faithful are most likely to be most familiar with, assuming their regular participation in weekly Sunday mass.

Among the most striking differences between the two English translations in question is the rendering of the response to the celebrant's greeting The Lord be with you (Latin: Dominus vobiscum), which is reiterated throughout the Mass. For about forty years English-speaking Catholics responded with And also with you, deprived of the transcendental dimension. In the current 
translation this has been changed into And with your spirit, much closer to et cum spiritu tuo of the Latin original.

The Penitential Act (the Confiteor) illustrates the trend towards the reduction of repetitions in ICEL 1973 and an attempt to restore such expressions in the 2010 version:

MR: $\quad$... mea culpa, mea culpa, mea maxima culpa ...

ICEL 1973: ... through my fault ...

ICEL 2010: ... through my fault, through my fault, through my most grievous fault ...

The Roman liturgy is full of such 'triplets', emphasizing the trinitarian dimension of Christian faith. Also, the superlative modifier maxima/most grievous appears to be irrelevant in the older edition of English missal.

Similarly, in the Gloria a sequence of five clauses in Latin is reduced to merely three in ICEL 1973, while ICEL 2010 provides a literal rendering:

MR: Laudamus te, benedicimus te, adoramus te, glorificamus te. Gratias agimus tibi propter magnam gloriam tuam ...

ICEL 1973: We worship you, we give you thanks, we praise you for your glory ...

ICEL 2010: We praise you, we bless you, we adore you, we glorify you, we give you thanks for your great glory ...

Apart from the 'compression' of five verbal structures into three, notice the omission of the adjective great modifying the noun glory in ICEL 1973 and its inclusion in ICEL 2010 (underlined above).

Further reduction of this sort in the same hymn can be observed in the following extract:

MR: $\quad \ldots$ qui tollis peccata mundi, miserere nobis; qui tollis peccata mundi, suscipe deprecationem nostram; qui sedes ad dexteram Patris, miserere nobis.

ICEL 1973: ... you take away the sin of the world: have mercy on us; you are seated at the right hand of the Father: receive our prayer.

ICEL 2010: ... you take away the sins of the world, have mercy on us; you take away the sins of the world, receive our prayer; you are seated at the right hand of the Father, have mercy on us.

Quite significantly, the reduced versions of ICEL 1973 apart from affecting the content of the text contribute to its simplification in terms of 
grammatical structure. It gives an impression that the authors of the older translation do not only seek the most natural English equivalent (in the spirit of dynamic equivalence), but actually put a lot of effort into producing an English text that is deliberately stripped of any traces of lexical and structural similarity to the Latin original.

Another important contrast between ICEL 1973 and ICEL 2010 has to do with the pronominal form at the beginning of the Creed: We believe (ICEL 1973) vs I believe (ICEL 2010). The revised version is a literal translation of the Latin Credo, and it favours the individual character of the profession of the faith over the communal nature of the liturgical celebration in general. In the same Creed, the Latin consubstantialem Patri is currently rendered by means of a loanword from Latin as consubstantial with the Father, whereas ICEL 1973 employs of one Being with the Father. This liturgical formula has been object of theological debate as some authors argue that the term being is potentially ambiguous in this context (cf. Shaw, Lang).

The difference between a more colloquial, frequently trivial, everyday vocabulary of the previous translation and more sophisticated archaic lexemes of the revised missal is exemplified by the English equivalent of the Latin calix in the consecration formula: cup in ICEL 1973 and chalice in ICEL 2010, again an instance of lexical borrowing from the language of the source text. In the same vein, another Latin loan oblation of ICEL 2010 replaces gift, smacking of banality typical of ICEL 1973. This is also found in the title of the priest's prayer following the washing of the hands before the consecration (Oratio Super Oblata): offerings (ICEL 2010) instead of gifts (ICEL 1973).

Another instance of trivialization of liturgical language in the older English texts is found in the celebrant's invocation before the Communion (the relevant differences are underlined):

MR: $\quad$ Ecce Agnus Dei, ecce qui tollit peccata mundi. Beati qui ad caenam $\underline{\text { Agni }}$ vocati sunt.

ICEL 1973: This is the Lamb of God who takes away the sins of the world. Happy are those who are called to his supper.

ICEL 2010: Behold the Lamb of God, behold him who takes away the sins of the world. Blessed are those called to the supper of the Lamb.

Most prominently, blessed substitutes for the blatantly trivial happy as the counterpart of the Latin beati. Again, ICEL 2010 contains the repetitions and archaisms absent from ICEL 1973. 
Preference for loyalty to the Latin source text in ICEL 2010 is exemplified by the response of the faithful to the above invocation:

MR: Domine, non sum dignus, ut intres sub tectum meum, sed tantum dic verbo, et sanabitur anima mea.

ICEL 1973: Lord, I am not worthy to receive you, but only say the word and I shall be healed

ICEL 2010: Lord, I am not worthy that you should enter under my roof, but only say the word and my soul shall be healed

The faithful rendering of ut intres sub tectum meum as that you should enter under my roof facilitates direct reference to the relevant scriptural text. The contrast between to receive you and that you should enter under my roof also points to a difference in perspective: anthropocentric (the action of the faithful in ICEL 1973) vs. theocentric (the action of God in ICEL 2010). The reluctance to adhere to the Latin of Missale Romanum in ICEL 1973 is corroborated by the use of the first-person pronoun as an equivalent of anima mea.

\subsection{SeleCted MASs PROPERS: ICEL 1973 VS. ICEL 2010}

Mass propers are the portions of liturgical texts that differ from day to day, or in some cases from season to season. Some of such prayers are unique to a given liturgical feast or commemoration of a given saint. This is represented, among others, by collects and post-communions.

A collect is a prayer recited by the celebrant before the first of scriptural readings. It has a fixed structure and consists of an initial reference to God, a mention of God's grand works, a petition addressed to God, and a concluding Trinitarian formula. All these components are captured in a single complex sentence, typical of the style of the liturgical Latin of the Roman rite. This structure seems to be disrupted in many cases of ICEL 1973 translation of collects. This can be observed, for instance in the Collect for the 2nd Sunday of Ordinary Time (the Trinitarian formula concluding each collect is omitted below for convenience):

MR : $\quad$ Omnipotens sempiterne Deus, qui caelestia simul et terrena moderaris, supplicationibus populi tui clementer exaudi, et pacem tuam nostris $\underline{\text { con- }}$ cede temporibus. 
ICEL 1973: Father of heaven and earth, hear our prayers, and show us the way to peace in the world.

ICEL 2010: Almighty ever-living God, who govern all things, both in heaven and on earth, mercifully hear the pleading of your people and bestow your peace on our times.

The part mentioning God's works (qui caelestia simul et terrena moderaris in MR, quite faithfully rendered in ICEL 2010 as who govern all things, both in heaven and on earth) is thoroughly omitted in ICEL 1973. Also, the petition is reduced in ICEL 1973: the adverb clementer is deleted and the noun populi is ignored, the phrase populi tui becoming the possessive our. Another case of omission has to do with the possessive determiner tuam of pacem tuam, thus disregarding the supernatural character of the peace that is asked for. Additionally, the neutral (prayer) or colloquial (show) vocabulary of ICEL 1973 corresponds to more formal and archaic counterparts in ICEL 2010 (pleading and bestow, respectively). In syntactic terms, the lack of the relative clause (included in the Latin original and in the revised English translation) makes the earlier English version of the collect become a mere coordination of two clauses rather than a complex sentence. This tendency to reduce complex sentential structures to much simpler constructions appears to be a general tendency throughout the 1973 translation.

An instance of glaring omission which constitutes one of many pieces of evidence that revision of the older translation was necessary is found in an extract from the Exsultet (or Solemn Proclamation of Easter), which is sung by the celebrant during the Easter Vigil:

MR: In huius igitur noctis gratia, suscipe, sancta Pater, laudis huius sacrificium vespertinum, quod tibi in hac cerei oblatione sollemni, per ministrorum manus de operibus apum, sacrosancta reddit Ecclesia.

Sed iam columnae huius praeconia novimus, quam in honorem Dei rutilans ignis accendit. Qui, licet sit divisus in partes, mutuati tamen luminis detrimenta non novit. Alitur enim liquantibus ceris, quas in substantiam pretiosae huius lampadis apis mater eduxit. $O$ vere beata nox, in qua terrenis caelestia, humanis divina iunguntur!

ICEL 1973: Therefore, heavenly Father, in the joy of this night, receive our evening sacrifice of praise, your Church's solemn offering.. Accept this Easter Candle, a flame divided but undimmed, a pillar of fire that glows to the honour of God! 
ICEL 2010: On this, your night of grace, O holy Father, accept this candle, a solemn offering, the work of bees and of your servants' hands, an evening sacrifice of praise, this gift from your most holy Church. But now we know the praises of this pillar, which glowing fire ignites for God's honour, a fire into many flames divided, yet never dimmed by sharing of its light, for it is fed by melting wax, drawn out by mother bees to build a torch so precious. O truly blessed night, when things of heaven are wed to those of earth, and divine to the human!

The relevant part in ICEL 1973 is hardly comparable to either the Latin original or the other English translation. The sheer size of ICEL 2010 suggests that English cannot be expected to be more concise than liturgical Latin. The impoverished ICEL 1973 at best qualifies as a remote paraphrase, poorly summarizing the whole.

\section{CONCLUSION}

A gradual and moderate introduction of vernaculars to celebration of the Roman Catholic Mass postulated in the Vatican II document on the liturgy (Sacrosanctum concilium, 1963) could be viewed as another step in the organic development of the Roman rite (cf. Reid). However, what actually happened during the post-conciliar liturgical reform was a kind of rupture with the earlier 'linguistic' tradition of Catholicism. There are two dimensions of this rupture: first, Latin was almost entirely substituted by vernaculars, and secondly, in many cases vernacular translations aggravated the situation be employing a language variety that appears to be an antihieratic language.

While the introduction of the revised version of the Roman Missal in English (2010) has been extensively motivated on the intra-ecclesial theological (doctrinal and pastoral) grounds, as reflected in the guidelines of Liturgiam authenticam, the analysis of the selected linguistic aspects of the two texts confirms that ICEL 1973 and ICEL 2010 are two translations that significantly differ in style and that ICEL 1973 is a version that is hardly suitable for the purpose of Christian worship as along as it is assumed that liturgical language within Catholicism (and possibly beyond) should be a specific language variety, known as a sacred or hieratic language in the sense of Mohrmann or Crystal. The revised English translation of the Roman Missal seems to be a step on the way towards hieratic or liturgical English, 
assumed by Liturgiam authenticam (see $L A$ no. 27 above), since the English of ICEL 2010 includes a number of properties of hieratic language, indeed it could probably be called a moderately hieratic variety of English. ${ }^{4}$

\section{WORKS CITED}

Burton, Philip. The Old Latin Gospels: A Study of Their Texts and Language. Oxford Early Christian Studies. Oxford University Press, 2000.

Coleman, Robert. "Vulgar Latin and the Diversity of Christian Latin". Actes du I ${ }^{e r}$ Colloque international sur le latin vulgaire et tardif, edited by Jozsef Herman, Niemeyer, 1987, pp. 37-52.

Crystal, David. "A liturgical language in a linguistic perspective". New Blackfriars vol. 46, 1964, pp. 148-156.

Crystal, David. "Liturgical language in a sociolinguistic perspective". Language and the Worship of the Church, edited by David Jasper and R.C.D. Jasper. Macmillan, 1990, pp. 120-146.

Dobszay, Laszlo. The Restoration and Organic Development of the Roman Rite. T\&T Clark, 2010.

Elliot, Peter John. "Liturgical language. A question of truth". Adoremus Bulletin vol. 13-4, 2007, http://www.adoremus.org/0607LiturgicalTranslation.html. Accessed 13 May 2013.

Fortescue, Adrian. The Mass: A Study of the Roman liturgy. Longmans, Green and Co., 1912.

Gamber, Klaus. The reform of the Roman liturgy: Its problems and background. Transl. by Klaus D. Grimm. Una Voce Press, 1993.

Jungmann, Josef Andreas. The Mass of the Roman rite: Its origins and development. [Missarum sollemnia]. Vols. 1-2. Translated by Francis A. Brunner. Benziger Brothers, 1951-55.

Kalekas, D.J. "Liturgical crisis in the Church". Sacred Music vol. 108-2, 1981, pp. 9-16.

Lang, Uwe Michael. The voice of the Church at prayer. Reflections on liturgy and language. Ignatius Press, 2012.

Liturgiam authenticam. 2001, http://www.vatican.va/roman_curia/congregations/ccdds/ documents/ rc_con_ccdds_doc_20010507_liturgiam-authenticam_en.html. Accessed 07 Oct. 2014.

Marini, Piero. A challenging reform. Realizing the vision of the liturgical renewal. Edited by Mark R. Francis, John R. Page, Keith F. Pecklers. Liturgical Press, 2007.

Mohrmann, Christine. Liturgical Latin: Its Origins and Character. Burns and Oates, 1959.

Mohrmann, Christine. "The Ever-Recurring Problem of Language in the Church". Theology of Renewal, vol. 2, 1968, pp. 204-220.

Nida, Eugene. Toward a Science of Translating. Brill, 1964.

Pecklers, Keith. Dynamic Equivalence. The Living Language of Christian Worship. The Liturgical Press, 2003.

Pecklers, Keith. The Genius of the Roman Rite. On the Reception and Implementation of the New Missal. Burns and Coats, 2009.

Pskit, Wiktor. "Części zmienne Mszy św. w przekładzie: wybrane kolekty w dwóch angielskich wersjach Novus Ordo Missae”. Poznańskie Spotkania Językoznawcze vol. 34, 2017, pp. 125-139.

\footnotetext{
${ }^{4}$ Research presented here is part of a larger project aimed at a more comprehensive study of ICEL 1973, ICEL 2010 and a more recent liturgical book representing the Roman rite, viz. Divine Worship, used by the Ordinariate for former Anglicans.
} 
Pskit, Wiktor. "O języku liturgii rzymskokatolickiej na przykładzie angielskiej wersji Mszału Pawła VI”. Intertekstualność a Słowo Boże, czyli o języku biblijno-religijnym w tekstach kultury, część II, edited by Małgorzata K. Frąckiewicz and Andrzej J. Najda. Instytut Papieża Jana Pawła II, 2018, pp. 179-196.

Ratzinger, Joseph. Milestones. Memoirs 1927-1977. Ignatius Press, 1998.

Ratzinger, Joseph. Collected works: Theology of the liturgy, edited by Michael J. Miller. Transl. by John Saward, Kenneth Baker, Henry Taylor et al. Ignatius Press, 2014.

Reid, Alcuin. The organic development of the liturgy. Ignatius Press, 2005.

Sacrosanctum concilium, Second Vatican Council, Constitution on the Sacred Liturgy (4 December 1963). Acta Apostolicae Sedis 56 (1964): 97-134. English translation: http://www.vatican.va/ archive/hist_councils/ii_vatican_council/documents/vat-ii_const_19631204_sacrosanctumconcilium_en.html. Accessed 11 Mar. 2014.

Schuler, Richard J. "“Success' of the liturgical reform”. Sacred Music vol. 108.4, 1981, pp. 3-4.

Shaw, Russell. "Making the Case for 'Consubstantial"'. Adoremus Bulletin vol. 16-8, 2010, https://adoremus.org/2010/11/15/Making-the-Case-for-quotConsubstantialquot/. Accessed 20 Oct. 2018.

\title{
MSZAŁ RZYMSKI W JEZYKU ANGIELSKIM PO SOBORZE WATYKAŃSKIM II: WSTĘPNA ANALIZA PORÓWNAWCZA DWÓCH ANGIELSKICH PRZEKŁADÓW
}

\author{
Streszczenie
}

Po Vaticanum II doszło do istotnych zmian w obrzędach Mszy św. sprawowanej według rytu rzymskiego. Należy do nich z pewnością odejście od łaciny i przejście na języki narodowe w liturgii. Jeśli chodzi o warstwę werbalną to, w pierwszym rzędzie, doszło do znacznej redukcji ilościowej tekstów liturgicznych (w porównaniu to tekstów sprzed reformy liturgicznej po Soborze Watykańskim II). Drugi wymiar zmiany na płaszczyźnie językowej - będący w pewnej mierze konsekwencją odejścia od uniwersalizmu łaciny - to daleko posunięte rozbieżności między oryginalnym tekstem, tzw. editio typica, zreformowanego Mszału Rzymskiego (1969/1970) a jego tłumaczeniami na niektóre spośród języków narodowych (np. angielski, niemiecki). W niniejszym opracowaniu omówione są wybrane fragmenty tekstów mszalnych wskazujące na różnice między dwoma przekładami angielskimi, tj. wersją z 1973 r. (będącą w użyciu przez prawie 40 lat) oraz nowym tłumaczeniem z 2010 r. Analiza ma charakter wstępnego badania i skupia się na różnicach leksykalnych, morfologicznych i składniowych. Nawet tak wyrywkowe porównanie pozwala dostrzec dwie rozbieżne tendencje w podejściu do przekładu tekstów na potrzeby kultu chrześcijańskiego, skutkujące tekstami, które w istotnej mierze różnią się pod względem treści, stylu i emfazy.

Słowa kluczowe: Mszał Rzymski; język liturgiczny; język hieratyczny; przekład angielski. 